\title{
10
}

\section{Understanding Soil Change: Institutional Requirements to Ensure Australia's National Preparedness}

\author{
Neil McKenzie
}

\section{Key Points}

- Globally, there is increasing awareness of threats to soil function, finite areas of arable land and apparent yield plateaus of major crops. Better soil management is needed so that nutrients are conserved, water use is improved and emissions are reduced.

- Some of Australia's soil management challenges are immediate and obvious (e.g. widespread acidification of cropping lands). Other problems (e.g. erosion, nutrient imbalances, soil carbon loss and compaction) are subtler, but equally important in the long term.

- A concerted effort to improve soil management in Australia requires improving the diagnostic systems for determining when and where soil function is being compromised; implementing sustainable systems of land use that restore or enhance soil function; and developing more effective institutional arrangements for soil information. 
- Over the last 25 years, the provision of soil information in Australia has relied on informal collaboration between national, state and territory agencies. Despite many achievements, the current arrangements are no longer viable.

- Investments into the national soil information system should generate substantial economic benefits. These benefits arise primarily from increases in agricultural productivity and avoidance of costs in other soil-dependent industries. This is before consideration of the equally large societal and ecosystem service benefits associated with better soil and land management.

\section{Introduction}

Soils are fundamental to life on Earth but, unlike food, energy, water and air, issues of security, access and quality are less immediate. Despite the patchy and often outdated sources of information on the condition of soil resources globally, there is now sufficient evidence to indicate that threats to soil function require a concerted response. This chapter summarises the observational and analytical capabilities that countries need to have if they are to understand the significance of soil change and manage accordingly. The evolution of Australia's soil information systems is reviewed. It is argued that current collaborative arrangements between state, territory and federal agencies are no longer viable. Proposals for the establishment of a formally mandated agency for mapping, monitoring and forecasting the condition of soils are considered, and it is suggested that integration is necessary with national information systems for land use and management. The resulting land resource information systems are prerequisites for achieving sustainable soil management, mitigating against climate change and optimising the productivity of Australian landscapes (Johnston et al., 2003). 


\section{The New Global View on Soil Use and Management}

The first State of the World's Soil Resources report by the Intergovernmental Technical Panel on Soils (ITPS, 2015a) concluded that:

Human pressures on soil resources are reaching critical limits. Further loss of productive soils will amplify food-price volatility and potentially send millions of people into poverty. This loss is avoidable. Careful soil management can increase the food supply, and provides a valuable lever for climate regulation and a pathway for safeguarding ecosystem services. (p. xix)

The ITPS went on to state that:

While there is cause for optimism in some regions, the overwhelming conclusion from the report is that the majority of the world's soil resources are in only fair, poor or very poor condition. The most significant threats to soil function at the global scale are soil erosion, loss of soil organic carbon, and nutrient imbalance. The current outlook is for the situation to worsen unless concerted actions are taken by individuals, the private sector, governments and international organisations. (p. xix)

Knowledge of soil and land resources is the foundation for achieving sustainable soil management. However, the distribution and characteristics of soils in any district or nation are neither obvious nor easy to monitor. Consequently, understanding whether a land use is well matched to the qualities of the soil requires some form of diagnostic system-both to identify the most appropriate form of management and to monitor how the soil is functioning (McKenzie, 2014). Three important components of the diagnostic system necessary for sustainable land use and management are:

- an understanding of how soils vary across the landscape (e.g. maps of soil properties and functional types)

- an ability to detect and interpret soil change with time (e.g. via monitoring sites and long-term experiments)

- a capacity to forecast the likely state of soils under specified systems of land management and climates (e.g. through the use of simulation models). 
The Revised World Soil Charter adopted by all member states of the United Nation's Food and Agriculture Organization (2015) recommended that all nations require coordinated soil information systems similar to those for economic data, weather and water resources that exist in many countries. Further, these national soil information systems need to be integrated with the emerging global soil information system.

\section{The Australian Context}

Australia is one of the countries that gave the ITPS some cause for optimism. However, even in Australia, soil acidification, unsustainable rates of soil erosion, loss of soil organic carbon and nutrient imbalances (deficiencies and excesses) are recognised as significant threats to soil function, and remain difficult to ameliorate (ITPS, 2015b). If left unchecked, these problems will constrain Australia's ability to take advantage of agricultural opportunities created by a growing population and demand for exports. A concerted effort to further improve soil management is required; this needs to include not only better diagnostic systems for determining when and where soil function is being compromised, but also effective systems for developing and implementing sustainable systems of land use that restore or enhance soil function. The benefits of achieving sustainable soil management are substantial. They include:

- increased income for farmers and other players within the food supply system

- increased economic activity through the development of service industries that support sustainable soil management

- improved intergenerational equity, particularly for farming families

- more efficient and effective mitigation and adaptation to climate change

- greater food security

- positive externalities including improved water quality and landscape amenity.

It is difficult to estimate the likely return on investments into sustainable soil management. However, the National Committee on Soil and Terrain (NCST, 2013) estimated that an annual investment of $\$ 100$ million into the national soil information system could generate economic benefits worth $\$ 2$ billion per annum by 2020 . These benefits arise primarily 
from increases in agricultural productivity and avoidance of costs in other soil-dependent industries that potentially amount to hundreds of millions of dollars per year. This estimate does not include the equally large societal and ecosystem service benefits associated with better soil and land management, particularly carbon sequestration (e.g. Minasny, McBratney, Malone \& Stockmann, 2015). These potential benefits are significant for the Australian economy; however, a more thorough analysis is necessary to confirm the scale of returns and to identify priorities for investments.

\section{Institutional Evolution}

The evolution of institutions for managing soil resources parallels the recent history of land use in Australia. The initial impact of European colonisation on soils in most parts of Australia was profound; in some areas, catastrophic. The severity of soil degradation, particularly in the 100 years after 1850, was extreme, resulting in declining crop yields and the Dust Bowl years of the 1930s and 1940s (Angus, 2001; Bolton, 1981; McKenzie, Isbell, Jacquier \& Brown, 2004; McTainsh \& Boughton, 1993). The large economic, social and environmental costs led to a range of institutional responses. At a conference of Commonwealth and state ministers held in Adelaide in August 1936, it was agreed that each state would establish a committee to study the problems of soil erosion and conservation, and suggest solutions; the Council for Scientific and Industrial Research (now the Commonwealth Scientific and Industrial Research Organisation [CSIRO]) was to cooperate with these committees (Australian Bureau of Statistics, 1963; Soil Conservation Committee, 1938). State soil conservation authorities with supporting legislation were subsequently established and coordination was eventually achieved through the Standing Committee of Soil Conservation, which was established in 1946. This committee reported to the Australian Agricultural Council, which had a remit to ensure consultation among Australian governments on economic aspects of primary production. Variants of this arrangement endured for more than 60 years, with the responsibility for soil resources eventually passing to the Natural Resource Management Ministerial Council (NRMMC), which had responsibility for land and water management. 
The Collaborative Soil Conservation Study (CSCS, 1978a, 1978b) conducted by the Australian, state and territory governments provided a comprehensive overview of the technical and institutional issues affecting soil management across the country. It laid the groundwork for the establishment of the National Soil Conservation Program in 1983. This coincided with continuing public concern over the extent and severity of land degradation; the large dust storm that engulfed Melbourne in February 1983 brought this into sharp relief. The concern did not abate, but instead contributed directly to the rise of the Landcare movement, which emphasised participative engagement and local action. The Landcare movement began with an unlikely alliance between traditional opponentsconservationists and farmers - and grew into a movement with thousands of groups in Australia and other countries (Campbell, 1992). The activities of Landcare groups transformed many landscapes; large areas were revegetated and restored through their efforts. The strength of Landcare lay in the community groups and networks that conceived their own visions and set goals for local and regional environmental action, with government and corporate support (Youl, Marriot \& Nabben, 2006).

Unprecedented investment into natural resource management from the Australian Government was associated with the rise of Landcare. Several large natural resource management programs built upon the National Soil Conservation Program - the National Landcare Program (1989), Natural Heritage Trust (1997) and Caring for our Country (2008) invested billions of dollars into natural resource management. It is difficult to accurately assess the effects of these programs, for although significant improvements in natural resource conditions have been achieved, it is generally acknowledged that the scale of management actions may only be slowing, rather than reversing, the negative impacts that would occur without intervention (e.g. Auditor General, 2008; Australian Government, 2013; Pannell et al., 2012).

Major land use conflicts over the use of high-quality soils have figured prominently during the last decade (e.g. Williams, 2015); however, the scale of investment into general natural resource management programs has declined. The reasons are complex, but the following factors are significant:

- major improvements in soil and land management during the last 25 years (e.g. ITPS, 2015b; State of the Environment [SoE], 2011), which have quite likely contributed to a perception that soil and land management problems have been solved 
- the difficulty of demonstrating returns on investment from large natural resource management programs, resulting in public funds being directed elsewhere (e.g. health, education and national security)

- the concerns over some major problems such as dryland salinity lessening, partly due to seasonal climate shifts and also because the initial projections were overstated

- the end of the Millennium Drought (van Dijk et al., 2013), water reforms and significant improvements in water resource information systems contributing to a sense that water problems have been solved

- the Global Financial Crisis and end of the resources boom forcing governments to reduce expenditure

- government agencies responsible for natural resource management struggling to find a compelling narrative and mode of operation that could compete with other government priorities—one indication of this was the abolition of the NRMMC and Land and Water Australia.

Despite these developments, many of the less obvious-but chronicissues affecting the soil resources of Australia remain. However, it is unreasonable to expect governments and industries to invest in sustainable soil management unless there is compelling evidence that these chronic issues require a response. Such evidence will not be forthcoming until there is an overhaul of Australia's soil information system.

\section{Australia's Soil Information System}

Most reviews of the soil knowledge system in Australia highlight institutional complexity, inconsistency of technical methods, limited economies of scale, ineffective mechanisms for funding and lack of a long-term strategy (e.g. Beckett \& Bie, 1978; Campbell, 2006; CSCS, 1978a, 1978b; McKenzie, 1991; Taylor, 1970; Wood \& Auricht, 2011). While some of these problems have been solved, significant institutional constraints remain. McKenzie (2014) summarised these constraints as follows:

- All levels of government need reliable information on soil resources, but no single level of government or department has responsibility for collecting this information on behalf of other public sector agencies. 
- Public and private interests in soil are large and overlapping, but mechanisms for co-investment by public and private agencies have not been developed.

- Market failure in relation to the supply and demand of soil information is a significant and widespread problem. In the simplest case, beneficiaries of soil information do not pay for its collection and this reduces the pool of investment for new survey, monitoring and experimental programs.

- Partly, as a result of the above, most soil information-gathering activities are currently funded through short-term government programs, private companies and individuals, or in response to specific regulatory requirements (e.g. environmental impact statements). These have not produced the enduring, accessible and broadly applicable information systems that are needed to meet the requirements of nearly all stakeholders.

Despite these significant challenges, the Australian soil information system is recognised for being innovative, collaborative and responsive to contemporary issues. This is largely due to the enduring and effective partnerships between operational agencies and research groups that have been responsible for a range of innovations, including digital soil mapping, proximal sensing and web-based delivery of information services (Arrouays et al., 2014a, 2014b; Grundy et al., 2015; Hicks, Rossel \& Tuomi, 2015).

\section{The Collaborative Model}

Despite several previous proposals for the establishment of a national soil information agency (CSCS, 1978b; Taylor, 1970), a strategic review of soil survey and land evaluation activities by McKenzie (1991) concluded that a voluntary and collaborative model was most appropriate for addressing the technical and institutional problems apparent at that time. As a result, the Australian Collaborative Land Evaluation Program (ACLEP) was established to develop a coordinated approach to land resource assessment across Australia (Hallsworth, 1978). The program included all Australian, state and territory government agencies involved with land resource assessment. ACLEP was jointly funded by the Australian Government (initially through its National Landcare Program) and CSIRO. In many ways, the model was a continuation of the original institutional arrangements established in 1936. 
ACLEP aimed to encourage sustainable land use and environmental protection in Australia by promoting better procedures for acquiring and using land resource information in government and private industry. This was achieved by setting national standards for land resource assessment, providing a forum for communication between technical specialists, attempting to develop a network of soil and land reference sites across Australia and encouraging research into methods for land resource assessment. ACLEP received strategic direction from the NCST (formerly the Working Group on Land Resource Assessment) and, for most of its existence, has had a formal line of reporting to the relevant ministerial council. ${ }^{1}$ In its current form, ACLEP has the following objectives:

- provide coordinated, scientific assessment and monitoring of Australia's soil and land resources

- develop and promote methods and standards for soil measurement, land resource survey and monitoring of soil condition

- build and support coordination, collaboration, partnerships and development of skills and capacity through improved communication

- be the primary contact point for information on Australia's soil and land resources and related national assessments

- provide a focus for the collection, collation, management, dissemination and analysis of nationally consistent, integrated data and information on soil and land resources through the Australian Soil Resource Information System and the CSIRO National Soil Archive.

During its 23 years of operation, ACLEP has relied primarily on project funding from the Australian Government (the Department of Agriculture and Water Resources and its precursors) with matching resources from CSIRO. It has also been able to entrain broader support from CSIRO (e.g. computing infrastructure) and in-kind contributions from state and territory agencies.

ACLEP has had three main phases:

1. 1990-2000: this phase coincided with the Decade of Landcare when state and territory agencies, with partnership funding from the Australian Government, undertook the Accelerated Program of Land

1 Initially, the ACLEP reported to the Australian Soil Conservation Council, later to the Natural Resources Ministerial Council, and then to the Primary Industries Ministerial Council until it was disbanded in 2013. It now reports indirectly to the Standing Council on Primary Industries, but the scope of the NCST extends well beyond agriculture. 
Resource Assessment. Some states (e.g. South Australia and Western Australia) were able to complete new surveys across their agricultural lands. Other states and territories adopted different strategies. During this period, ACLEP focused on supporting the partner agencies through capacity building, development and publication of standards, and testing of new survey methods. The ACLEP newsletter provides a comprehensive catalogue of activities during this period.

2. 2000-10: the focus during this period was on the communication of soil and land resource information to a broad range of users, while at the same time providing technical support for new methods of digital soil mapping (e.g. Henderson, Bui, Moran \& Simon, 2005; McKenzie, Grundy, Webster \& Ringrose-Voase, 2008). The national soil information system was upgraded to become one of the world's first online national soil information systems. Collaborations were pursued with other technical groups to provide assessments and information at the continental scale (e.g. NLWRA, 2001, 2002; Peverill, Sparrow \& Reuter, 1999). ACLEP was also heavily involved in developing technical recommendations and guidance on monitoring the condition of Australian soils (Grealish, Clifford, Wilson \& Ringrose-Voase, 2011; McKenzie \& Dixon, 2007; McKenzie, Henderson \& McDonald, 2002). This period saw initial steps taken to build stronger links between technical programs and proposals for a national soil policy (Campbell, 2008). A significant effort was directed towards improving public understandings of soils and soil management (McKenzie et al., 2004).

3. 2010-15: with the exception of Tasmania and the Northern Territory, most field survey and monitoring programs had been curtailed by this time, and the focus for ACLEP was on improving online access to existing soil information. Opportunities in geospatial technologies led to the development of new standards for soil data systems and web-based services. Ongoing support was provided for synoptic assessments (e.g. ITPS, 2015b; SoE, 2011), and a major upgrade of the National Soil Archive was completed (Karssies \& Wilson, 2015). The latter activity was especially significant because it allowed new methods of proximal sensing to be deployed on archived samples and, in the process, generated large new datasets for the country (e.g. Hicks et al., 2015). The most significant achievement of this period involving all partners was the development of the Soil and Landscape Grid of Australia (Grundy et al., 2015). This was an internationally significant achievement because it was the first continental-scale implementation 
of the GlobalSoilMap technical specifications (Arrouays et al., 2014a) that are a key component of the emerging global soil information system (Global Soil Partnership, 2014).

It is difficult to provide a detached and objective view of the effectiveness of the collaborative model, and ACLEP in particular. However, it is worth noting the following:

- Users of soil information now have unprecedented access to harmonised soil data and information collected over more than 50 years.

- Major technical advances and major new products have been delivered because of the network and collaborative arrangements fostered by ACLEP.

- ACLEP provided a particularly effective pathway-to-impact for research teams in universities (e.g. University of Sydney) and CSIRO.

Despite the long record of achievement, it would appear that the collaborative model forged by ACLEP is no longer viable for several reasons:

- Most state agencies have stopped their field programs of soil survey and monitoring. As a result, the map coverage is now out-of-date and monitoring networks are not being established or maintained.

- A closely related issue is the demographic profile of the current cohort of experienced pedologists. Most were trained in the 1980s and 1990s and participated in the Accelerated Program of Land Resource Assessment. The expertise, and especially the field knowledge, held by these experts is not being passed onto a new generation of soil and land resource specialists.

- The formal programs for funding research (e.g. via the Rural Research and Development Corporations and the Australian Research Council) are more enduring and better organised than those for operational programs of land resource survey and monitoring. At present, there are very few sources of funds for the latter.

- ACLEP and its related activities have been funded through the major natural resource management programs listed earlier. However, none of these programs are compelled to fund operational survey and monitoring programs, and there are no jurisdictional mandates to compel governments to continue such programs. This contrasts with 
other areas, such as weather and climate, in which legislation provides the formal basis for data-gathering programs. The levels of funding for ACLEP have declined in real terms in recent years.

- There has been a general trend towards smaller national, state and territory agencies — the traditional homes for land resource survey and monitoring.

- The CSIRO has maintained its long tradition of supporting land resource surveys, but the investment is considerably less than in previous decades when several divisions were actively involved (e.g. the former Division of Soils, and the Division of Land Use Research and its successors). The CSIRO continues to have a role in undertaking research and development to support survey and monitoring programs; however, it has no formal mandate to provide resources for the ongoing operational activities that are necessary if Australia is to have the information services it needs to ensure sustainable soil management.

\section{Barriers to Putting Soils on the National Agenda}

Institutional reform is necessary if Australia is to have a national soil information system that is compatible with the broader global effort. Any significant institutional reform requires public support and engagement by policymakers, politicians, industry groups and civil society. However, numerous significant barriers limit public awareness of soil issuesfor example:

- Most people do not have a clear view of the condition of the soil resources upon which their lives ultimately depend. One cause is increasing urbanisation and the reality that the proportion of human labour devoted to working the soil has steadily decreased through the past century. Further, most people are now protected from local resource depletion due to trade and the area of land and water used to support them being scattered all over the planet (ITPS, 2015a).

- Most threats to soil function are chronic and long-term-soil erosion, acidification and depletion of carbon and nutrients occur over decades. Some of these changes can be difficult to detect and there is a risk that management responses will not occur until critical and irreversible thresholds have been exceeded. 
- Institutional responses to natural resource problems are often triggered by major polarising events (e.g. droughts, fires and floods). Apart from dust storms, which are much less frequent than during the 1930s and 1940s (SoE, 2011), changes in soil condition rarely rate a mention in the mainstream news media, although soil contamination is an occasional exception because it may directly affect human health and food quality.

- For most primary industries (e.g. cropping, grazing, forestry and horticulture), soils are a means to an end. Management systems tend to focus on the final product or readily measured indicators along the supply chain (e.g. yield or market price). Soils are acknowledged as important; however, other factors that have an immediate impact on profitability are often prioritised. Consequently, insufficient investment into research, development and extension can easily occur.

- Soil scientists who draw attention to the lack of investment into soil activities can be readily dismissed as self-interested. The recent emergence of independent public advocates on soil issues has started to address this problem (e.g. former diplomat and Governor of Queensland Penny Wensley and Australia's Advocate for Soil Health Major General Michael Jeffery).

- There have been major improvements in soil and land management during the last 25 years - conservation farming, controlled traffic, cell grazing and the more general achievements of the Landcare movement (e.g. Natural Decisions Pty Ltd, 2015). This has likely contributed to a perception that soil and land management problems have been solved.

- Australia is a food exporter and its citizens have access to an abundance of inexpensive, high-quality food. Issues relating to food security do not figure in public discourse, except in relation to international affairs, and when famines occur in distant countries.

Additional factors limiting the consideration of soils by policymakers include a lack of ready access to the evidence needed for policy action and the challenge of dealing with property rights for a natural resource that is often privately owned, yet vital for the public good (ITPS, 2015a). All these factors contribute to our current lack of institutional preparedness-both domestically and internationally. 


\section{The Public Sector Role}

The decision, in 1991, to establish ACLEP using a voluntary and collaborative model was appropriate, particularly given the technical strength of some state and territory agencies. However, the situation has changed. A more enduring and self-sustaining system is now required, not only for soils, but also for natural resource information more generally.

Craemer and Barber (2007) outlined some of the market failure arguments relevant to the development of a 'business case' for public investment in soil information. These related to the presence of externalities, which were important to basic research and development, and information failures within markets. They noted the significance of information as infrastructure, and the importance of soil information being collected once and then used for many different purposes. While Craemer and Barber provided a valuable starting point for developing the economic case for investing in soil information, more work still needs to be done. It is assumed that there is a legitimate role for the public sector in gathering and providing soil information. However, given the privateand public-good nature of soil resources, it is also assumed that some form of public-private model would be appropriate.

The NCST (2013) has recently proposed a comprehensive plan for re-engineering the national soil information infrastructure, so that it can provide the required data and information to regularly assess the condition of soils and their responses to land management across Australia. A prerequisite for implementing the plan is establishing a formal and enduring mandate for soil resource assessment. One possible mechanism is via the incorporation, by legislation, of soil resource assessment activities into one or more agencies. This mandate is essential because of the long time frames required to build the soil resource information base and monitor soil change over several decades. The second key institutional issue identified by the NCST relates to the organisational and business model. Three options were proposed:

1. Create a new Bureau of Soil Resources modelled on the much larger Bureau of Meteorology and Australian Bureau of Statistics: the Bureau of Soil Resources would have a legislated charter to serve all levels of government and engage with private sector activities to maximise the net benefit for Australia. The bureau would be responsible for survey, monitoring and technical activities. It would have a workforce 
of technical specialists and significant capital assets (e.g. field survey capability, laboratories and computing infrastructure). The Bureau of Soil Resources could be administered by an existing agency to minimise administrative costs.

2. Establish a legislated program within an existing Australian government agency: the program would have a central management team to coordinate the survey, monitoring and technical activities, but most of these would be contracted out to either state and territory agencies or the private sector. The balance between in-house technical work and externally contracted work would require careful management to avoid the loss of corporate knowledge and intellectual capital that can occur with such arrangements.

3. Formation of a new organisation with a business model and structure similar to current arrangements for Cooperative Research Centres: the legislation and agreements supporting such a centre would differ from that of a Cooperative Research Centre because of the requirement for the organisation to be enduring.

The experience of the last 15 years suggests that the first option is preferable, although it is recognised that Australian governments have little appetite for establishing new organisations (e.g. Morton \& Tinney, 2012).

\section{Soil Resources and Land Management}

The proposal by the NCST to establish an Australian Soil Assessment Program has recently stalled, primarily because of an institutional impasse and lack of political momentum. This may change; governments may see land use policy as once again being central to national prosperity. HatfieldDodds et al. (2015) outlined how new technologies and incentives could decouple economic and environment outcomes to enable progress towards sustainable prosperity. However, this requires greater commitment to land use planning and management, along with the necessary information systems as support.

If the activities of the land use mapping community were integrated with those traditionally undertaken by ACLEP, a strong case could be mounted for investment in natural resource information systems. Given that the Australian Collaborative Land Use and Management Program (ACLUMP) was founded on the same principles as ACLEP, and that 
many of the issues facing the land use mapping community are similar to those outlined above for the soil resource community, this is a natural development. The late Rob Lesslie was a leader in the establishment and operation of ACLUMP; he was extremely keen to integrate the work of his community with the work of ACLEP. The establishment of an Australian land management agency that would provide technical and policy support to achieve the sustainable and prosperous future identified by Hatfield-Dodds et al. (2015) would be a fitting memorial.

\section{References}

Angus, J. F. (2001). Nitrogen supply and demand in Australian agriculture. Animal Production Science 41, 277-88. doi.org/10.1071/EA00141

Arrouays, D., Grundy, M. G., Hartemink, A. E., Hempel, J. W., Heuvelink, G. B. M., Hong, S. Y., ... Zhang, G. L. (2014a). GlobalSoilMap: Toward a fine-resolution global grid of soil properties. Advances in Agronomy 125, 93-134. doi.org/10.1016/B978-0-12800137-0.00003-0

Arrouays, D., McKenzie, N. J., Hempel, J., Richer de Forges, A. C. \& McBratney, A. B. (Eds.). (2014b). GlobalSoilMap-basis of the global spatial soil information system: Proceedings of the 1st GlobalSoilMap Conference. London, UK: Taylor \& Francis Group.

Auditor General. (2008). Regional delivery model for the Natural Heritage Trust and the national action plan for salinity and water quality. Australian National Audit Office (Audit Report No. 21). Canberra, ACT. Retrieved from www.anao.gov.au/sites/g/files/net3721/f/ANAO Report_2007-2008_21.pdf

Australian Bureau of Statistics. (1963). Soil conservation [Year Book Australia 1963]. Retrieved from www.abs.gov.au/AUSSTATS/ abs@.nsf/allprimarymainfeatures/816FB6F65D2BA89ECA2573 AE00045D33?opendocument

Australian Government. (2013). Caring for our country 2008-2013. Achievements report: The synthesis chapter. Retrieved from www.nrm. gov.au/publications/achievements-report-synthesis 
Beckett, P. H. T. \& Bie, S. W. (1978). Use of soil and land system maps to provide soil information in Australia. Melbourne, VIC: CSIRO.

Bolton, G. C. (1981). Spoils and spoilers: Australians make their environment 1788-1980. Sydney, NSW: Allen \& Unwin.

Campbell, A. (1992). Landcare in Australia. Canberra, ACT: National Soil Conservation Program.

Campbell A. (2006). The Australian natural resource management knowledge system. Canberra, ACT: Land and Water Australia.

Campbell, A. (2008). Managing Australia's soils. A policy discussion paper. Retrieved from www.clw.csiro.au/aclep/documents/Soil-DiscussionPaper.pdf

CSCS (Collaborative Soil Conservation Study). (1978a). A basis for soil conservation policy in Australia. Commonwealth and state government Collaborative Soil Conservation Study 1975-77 (Report 1). Canberra, ACT: Australian Government Publishing Service.

CSCS. (1978b). Towards a national approach to land resource appraisal. Commonwealth and state government collaborative soil conservation study, 1975-77 (Report 2). Canberra, ACT: Australian Government Publishing Service.

Craemer, R. \& Barber, M. (2007). Building a business case for investment in soil information. Canberra, ACT: National Land and Water Audit and National Heritage Trust.

Food and Agriculture Organization. (2015). Revised world soil charter. Retrieved from www.fao.org/3/a-mn442e.pdf

Global Soil Partnership. (2014). Plan of action for pillar four of the Global Soil Partnership adopted by the GSP plenary assembly. Retrieved from www.fao.org/3/a-az921e.pdf

Grealish, G., Clifford, D., Wilson, P. \& Ringrose-Voase, A. (2011). National soil condition monitoring for soil $p H$ and soil carbon: Objectives, design, protocols, governance and reporting (Report 05/11 for Caring for our Country). Canberra, ACT: CSIRO Land and Water Science. 
Grundy, M. J., Rossel, R. V., Searle, R. D., Wilson, P. L., Chen, C. \& Gregory, L. J. (2015). Soil and landscape grid of Australia. Soil Research 53, 835-44. doi.org/10.1071/sr15191

Hallsworth, E. G. (1978). Purposes and requirements of land resource survey and evaluation. Commonwealth and state government collaborative soil conservation study (Report 3). Canberra, ACT: Department of Environment, Housing and Community Development, AGPS.

Hatfield-Dodds, S., Schandl, H., Adams, P. D., Baynes, T. M., Brinsmead, T. S., Bryan, B. A., ... McCallum, R. (2015). Australia is 'free to choose' economic growth and falling environmental pressures. Nature 527, 49-53. doi.org/10.1038/nature16065

Henderson, B. L., Bui, E. N., Moran, C. J. \& Simon, D. A. P. (2005). Australia-wide predictions of soil properties using decision trees. Geoderma 124, 383-98. doi.org/10.1016/j.geoderma.2004.06.007

Hicks, W., Rossel, R. V. \& Tuomi, S. (2015). Developing the Australian mid-infrared spectroscopic database using data from the Australian soil resource information system. Soil Research 53, 922-31. doi.org/ $10.1071 / \mathrm{sr} 15171$

ITPS (Intergovernmental Technical Panel on Soils). (2015a). Status of the world's soil resources (SWSR)—technical summary [Food and Agriculture Organization of the United Nations' website]. Retrieved from www.fao.org/documents/card/en/c/39bc9f2b-7493-4ab6-b024feeaf $49 \mathrm{~d} 4 \mathrm{~d} 01 /$

ITPS. (2015b). Regional assessment of soil change in the southwest Pacific. In SWSR Report (Chapter 15) [Food and Agriculture Organization of the United Nations' website]. Retrieved from www.fao.org/documents/ card/en/c/39bc9f2b-7493-4ab6-b024-feeaf49d4d01/

Johnston, R. M., Barry, S. J., Bleys, E., Bui, E. N., Moran, C. J., Simon, D. A. P. ... Grundy, M. (2003). ASRIS: The database. Australian Journal of Soil Research 41, 1021-36. doi.org/10.1071/SR02033

Karssies, L. \& Wilson, P. (2015). Soil archives: Supporting research into soil changes. IOP Conference Series: Earth and Environmental Science 25(1). doi.org/10.1088/1755-1315/25/1/012021 
McKenzie N. J. (1991). A strategy for coordinating soil survey and land evaluation in Australia. Glen Osmond, SA: CSIRO, Division of Soils.

McKenzie, N. J. (2014). Australian soils. In D. Lindenmayer, S. Dovers \& S. Morton (Eds.), Ten commitments revisited. Melbourne, VIC: CSIRO Publishing.

McKenzie, N. J. \& Dixon, J. C. (Eds.). (2007). Monitoring soil condition across Australia: Recommendations from the expert panels. Retrieved from www.asris.csiro.au/downloads/Monitoring\%20Soil\%20Condition \%20ver_4.doc

McKenzie, N. J., Grundy, M. J., Webster, R. \& Ringrose-Voase, A. J. (Eds.). (2008). Guidelines for surveying soil and land resources (vol. 2). Melbourne, VIC: CSIRO Publishing.

McKenzie, N. J., Henderson, B. \& McDonald, W. S. (2002). Monitoring soil change. Principles and practices for Australian conditions. Canberra, ACT: CSIRO Land and Water.

McKenzie, N. J., Isbell, R. F., Jacquier, D. W. \& Brown, K. L. (2004). Australian soils and landscapes: An illustrated compendium. Melbourne, VIC: CSIRO Publishing.

McTainsh, G. \& Boughton, W. C. (Eds.). (1993). Land degradation processes in Australia. Melbourne, VIC: Longman Cheshire.

Minasny, B., McBratney, A. B., Malone, B. \& Stockmann, U. (2015, 1 December). Eyes down: How setting our sights on soil could help save the climate. The Conversation. Retrieved from theconversation. com/eyes-down-how-setting-our-sights-on-soil-could-help-save-theclimate-51514

Morton, S. \& Tinney, A. (2012). Independent review of Australian government environmental information activity: Final report. Canberra, ACT: Australian Government. Retrieved from www.environment.gov. $\mathrm{au} /$ resource/independent-review-australian-government-environmental -information-activity 
NCST (National Committee on Soil and Terrain). (2013). Establishing the Australian cooperative soil assessment program. Supporting Australia's sustainable future through improved knowledge of Australian soils and their responses to land management. A report prepared by the National Committee on Soil and Terrain for the Soil Research Development and Extension Reference Group.

Natural Decisions Pty Ltd. (2015). Evidence for the economic impacts of investment in national Landcare programme activities [Australian Government website]. Retrieved from www.nrm.gov.au/publications/ economic-impacts-nlp-activities

NLWRA (National Land and Water Resources Audit). (2001). Australian agricultural assessment 2001. Canberra, ACT: National Land and Water Resources Audit.

NLWRA. (2002). Australia's natural resources: 1997-2002 and beyond. Canberra, ACT: National Land and Water Resources Audit.

Pannell, D. J., Roberts, A. M., Park, G., Alexander, J., Curatolo, A. \& Marsh, S. P. (2012). Integrated assessment of public investment in land-use change to protect environmental assets in Australia. Land Use Policy, 29, 377-87. doi.org/10.1016/j.landusepol.2011.08.002

Peverill, K. I., Sparrow, L. A. \& Reuter, D. J. (1999). Soil analysis: An interpretation manual. Melbourne, VIC: CSIRO Publishing.

Soil Conservation Committee. (1938). Report of the soil conservation committee. Adelaide, SA: Government Printer. Retrieved from history.pir.sa.gov.au/__data/assets/pdf_file/0011/168266/Soil_ Conservation2.pdf

SoE (State of the Environment Committee). (2011). Australia state of the environment 2011: An independent report to the Australian government minister for sustainability, environment, water, population and communities. Canberra, ACT: Department of Sustainability, the Environment, Water, Population and Communities.

Taylor, J. K. (1970). The development of soil survey and field pedology in Australia, 1927-67. Canberra, ACT: CSIRO Australia. 
van Dijk, A. I .J. M., Beck, H. E., Crosbie, R. S., de Jeu, R. A. M., Liu Y. Y., Podger, G. M., ... Viney, N. R. (2013). The millennium drought in Southeast Australia (2001-2009): Natural and human causes and implications for water resources, ecosystems, economy and society. Water Resources Research 49, 1-18. doi.org/10.1002/wrcr.20123

Williams, J. (2015). Soils governance in Australia: Challenges of cooperative federalism. International Journal of Rural Law and Policy 1, 4173.

Wood B. G. \& Auricht C. M. (2011). ASRIS/ACLEP user needs analysis. Brighton, SA: Auricht Projects.

Youl, R., Marriot, S. \& Nabben, T. (2006). Landcare in Australia: Founded on local action. Wallington, VIC: SILC and Rob Youl Consulting Pty Ltd. 
This text is taken from Land Use in Australia: Past, Present and Future, edited by Richard Thackway, published 2018 by ANU eView, The Australian National University, Canberra, Australia.

doi.org/10.22459/LUA.02.2018.10 